\title{
RIGHT TO LIFE IN HUNGARY AND IN THE EU: THE EVER-TROUBLESOME ISSUE OF ABORTION
}

\author{
Author \\ Ferenc Zoltán Simó (Jur.) \\ University of Debrecen (Hungary) \\ E-mail address: \\ simofredz@gmail.com
}

Lectors

\author{
Ferenc Mező (Ph.D) \\ University of Eszterházy (Hungary)
}

....and three anonymous reviewers

Ferenc Zoltán Simó (2020). Right to Life in Hungary and in the EU: the Ever-Troublesome Issue of Abortion. Különleges Bánásmód, 6. (4). 83-90. DOI 10.18458/KB.2020.4.83

\begin{abstract}
In relation to one of the human rights, right to life, most frequently there are, at least, two challenging fields might be brought up, one is death penalty, and the other is termination of pregnancy or abortion. If one intends to comprehend how abortion has been dealt with historically in the western legal tradition one must first come to terms with two quite different but interrelated historical trajectories, the ancient JudeoChristian condemnation of prenatal homicide as a wrong justifying retribution; and, there is the juristic definition of "crime" in the modern sense of the word.
\end{abstract}

Keywords: abortion, human rights, law, tradition, culture, European Union

Disciplines: law, politics

\begin{abstract}
Absztrakt
AZ ÉLETHEZ VALÓ JOG MAGYARORSZÁGON ÉS AZ EU-BAN: AZ ABORTUSZ ÖRÖKKÉ KÉNYES TÉMÁJA

Az abortusz, vagy más szóval terhesség megszakítás történelmileg is elismerten nagy fejtörést okozott a különböző kultúrák közeledésének kisérleteikor. A helyzet ma sem változott, az emberiség megosztottsága a témát illetően nem változott. A téma nem vesztette el aktualitását évszázados viták után sem. Azonban a jogi környezet a jogalkotók, és alkalmazók nézőpontja és értelmezéseik árnyaltabbak lettek, reagálva a társadalmi igényekre és változásokra.
\end{abstract}

Kulcsszavak: terhesség megszakítás, abortusz, jog, emberi jogok, élethez való jog, Európai Unió, Diszciplínák: jog, politika 
In connection with one of the human rights, right to life, most commonly there are, at least, two problematic fields may arise, one is death penalty, and the other is termination of pregnancy, or as it is commonly called/known, abortion. In case of Hungary, the first one is no longer an issue since one of the many conditions to join the European Union in 2004 was to abolish death penalty. Anyone who wants to understand how abortion has been treated historically in the western legal tradition must first come to terms with two quite different but interrelated historical trajectories.

On one hand, there is the ancient JudeoChristian condemnation of prenatal homicide as a wrong justifying retribution; on the other, there is the juristic definition of "crime" in the modern sense of the word, which distinguished the term severely from „sin” and „tort” and was knotted to the rise of Western jurisprudence. To find the act of abortion first identified as a crime in the West, one has to go back to the twelfth century, to the schools of ecclesiastical and Roman law in medieval Europe.

Wolfgang P. Müller tells the story of how abortion came to be criminalized in the West. As he shows, criminalization as a distinct phenomenon and abortion as a self-standing criminal category developed in tandem with each other, first being formulated coherently in the twelfth century at schools of law and theology in Bologna and Paris. Over the ensuing centuries, medieval prosecutors struggled to widen the range of criminal cases involving women accused of ending their unwanted pregnancies. In the process, punishment for abortion went from the realm of carefully crafted rhetoric by ecclesiastical authorities to eventual implementation in practice by clerical and lay judges across Latin Christendom.

Informed by legal history, moral theology, literature, and the history of medicine, Müller's book is written with the concerns of modern readers in mind, thus bridging the gap that might otherwise divide modern and medieval sensibilities (Müller, 2012).

For most Americans today, Roe v. Wade concerns just one thing: the right to choose abortion. But the Supreme Court's decision once meant much more. The justices ruled that the right to privacy encompassed the abortion decision. Grassroots activists and politicians used Roe - and popular interpretations of it - as raw material in answering much larger questions: Is there a right to privacy? For whom, and what is protected? As Mary Ziegler demonstrates, Roe's privacy rationale attracted a wide range of citizens demanding social changes unrelated to abortion. Movements questioning hierarchies based on sexual orientation, profession, class, gender, race, and disability drew on Roe to argue for an autonomy that would give a voice to the vulnerable. So did advocates seeking expanded patient rights and liberalized euthanasia laws. Right-leaning groups also invoked Roe's right to choose, but with a different agenda: to attack government involvement in consumer protection, social welfare, racial justice, and other aspects of American life.

In the 1980s, seeking to unify a fragile coalition, the Republican Party popularized the idea that Roe was a symbol of judicial tyranny, discouraging anyone from relying on the decision to frame their demands. But Beyond Abortion illuminates the untapped potential of arguments that still resonate today. By recovering the diversity of responses to Roe, and the legal and cultural battles it energized, Ziegler challenges readers to come to terms with the uncomfortable fact that privacy belongs to no party or cause (Ziegler, 2018).

There might be a number of issues and questions that may be brought up concerning the issue of termination of pregnancy. According to many scholars, these can be the following without offering a full list of them (Bayles \& Henley, 1989):

- Is it morally permissible to obtain an abortion? 
- Is abortion ever a violation of the moral rights of the fetus?

- Should abortion legally prohibited?

- Is the choice of obtaining ever the expression of a trait of character (for instance, selfishness)?

The above mentioned „list" can go on and on as the heated debate that surrounds it and divides the world into pros and contras. I may not be able to offer a solution or a definite answer to these question, my mere attempt is to examine the issue in Hungary and in the vicinity.

In order to analyze the issue of one of the universal human rights in Hungary, first, one needs to turn to the core document of Hungary, namely, the Fundamental Law of Hungary, which, compared to the constitutions of other countries, is relatively novel.

But, in contrary to its novel nature, under one of the titles one can find: FREEDOM AND RESPONSIBILITY.

Article I (1) and (2) state that „the inviolable and inalienable fundamental rights of MAN shall be respected. It shall be the primary obligation of the State to protect these rights. (2) Hungary shall recognise the fundamental individual and collective rights of man."

As it can be seen, Hungary commits itself to the protection of the above mentioned rights and, also recognizes both individually and collectively (The Fundamental Law of Hungary -25 April 2011. 78.).

As an exception from the general rule, this Act lays down the possibility of restriction as well.

„(3) The rules for fundamental rights and obligations shall be laid down in an Act. A fundamental right may only be restricted to allow the effective use of another fundamental right or to protect a constitutional value, to the extent ab- solutely necessary, proportionate to the objective pursued and with full respect for the essential content of such fundamental right.

(4) Fundamental rights and obligations which by their nature apply not only to man shall be guaranteed also for legal entities established by an Act".

Article II extends the scope of the Act to human dignity, human life, and foetus as well. It declares that "human dignity shall be inviolable. Every human being shall have the right to life and human dignity; the life of the foetus shall be protected from the moment of conception (The Fundamental Law of Hungary -25 April 2011. 7-8.)

Although one seems to feel that it might be easy to pinpoint the moment of conception, there are more and more arguments generated around this topic, not to mention its being double-natured by being both medical and legal issue as well.

\section{Abortion}

The question of terminating pregnancy is always a stern issue, which has the potential to divide nations. The need for regulation and state intervention cannot be questioned, but the method and the measure of this interference should be re-examined time after time.

As a general rule, a pregnancy can be terminated up to the twelfth week in Hungary. However, before a termination takes place the woman (and the father too if possible) has to go to Family Planning (Családvédelmi Szolgálat) twice to receive information/counseling about state support and adoption. There has to be a gap of three days between the two appointments. This first step provides a kind of background for making a decision, and, of course, it may be able to give a (legal) insight as well.

Also, any woman shall have counselling, and, pay for the termination and wait three days to have the 
abortion after her request. A session with a nurse is compulsory to discuss contraception and support the pregnancy should it be taken to term.

In the main, termination of pregnancy/abortion is legal in the following circumstances:

- On request

- To preserve the physical or mental health of the pregnant woman

- If the pregnancy is the result of rape or an act of incest

- If the foetus is severely physically or mentally impaired

- Economic or social reasons

There are special situations as well, which are out of the scope of the above mentioned. Pregnancies can be terminated up to the 24th week if severe foetal abnormalities are detected.

Since Hungarian constitution clearly states that „every human being shall have the right to life and human dignity; the life of the foetus shall be protected from the moment of conception" The Fundamental Law of Hungary-25 April 2011), one seems to face an embedded contradiction as well. Since as a general rule for special situations, terminations can be carried out at any stage of a pregnancy if a woman's life is in danger or when it is clear that the foetus is sufficiently damaged for it to be unable to survive.

\section{The Procedure}

Although abortion is legal in Hungary, it is not made easy or convenient, which may seem to go against preserving one's dignity as well. If that is the case, one might claim it to be unconstitutional, since the Fundamental Law of Hungary states without a doubt that ,human dignity shall be inviolable. Every human being shall have the right to life and human dignity" (The Fundamental Law of Hungary -25 April 2011); therefore, it seems justified (with some doubts, of course) to assume that any obstacles created to delay, to jeopardize, or to interrupt (intentionally) one's practice of (in this case) her rights can be seen unconstitutional. Obviously, this issue is not as easy as I have just described, thus, it needs a case by case (re)examination.

And, on the other hand, with the intentional obstacles, it may seem to protect the feotus, at least, indirectly. And, also, we can see that no-one is excluded, since even a foreigner can get an abortion, but only if she has a valid residence permit.

Women seeking a termination for a non-medical reason should do the following:

- Visit a gynaecologist to request a letter stating how far along the pregnancy is

- Visit a social worker at a district Family Welfare Office with the gynaecologist's letter, a valid residence permit and photographic identification. It is wise to take an interpreter, if necessary

- Re-visit the social worker at least 72 hours after the first visit, again with an interpreter if necessary. The social worker provides a hospital referral for a termination

- Make an appointment for the procedure at the chosen hospital. To do this, the gynaecologist's letter, the hospital referral, a valid residence permit and photographic identification are needed (I1).

Due to the lengthy nature of this process, women are strongly advised to start seeking approval for an abortion for non-medical reasons, well in advance of the 12-week deadline.

There are other conditions to fulfill in case of termination of pregnancy, since women with Hungarian health insurance can visit any state clinic to obtain the letter from a gynaecologist. And, at the second visit to the Family Welfare Office, the woman is given a postal cheque in order to cover 
the costs of a termination at a public clinic or hospital. The cheque shall be paid into a post office and the receipt given as proof of payment at the hospital. In case of private doctors, they can set their own fees.

\section{Abortion Method and Contraception}

Hungary takes it very seriously, because surgical abortions are the only legal method presently available in Hungary. The procedure must take place in a hospital or clinic. But, it needs mentioning there is an escalating demand to legalize other solutions as well, one of them would be home birth. The issue of home birth is much debated and divides both legal and medical experts.

\section{Ternovsky v. Hungary}

14 December 2010

The applicant made a complaint about being denied the opportunity to give birth at home, arguing that midwives or other health professionals were effectively dissuaded by law from assisting her. Their rejection derived from the risk of being prosecuted. (There had recently been at least one such prosecution.) The Court found that the applicant was in effect not free to choose to give birth at home because of the permanent threat of prosecution faced by health professionals and the absence of specific and comprehensive legislation on the subject, in violation of Article 8 (right to respect for private and family life) of the Convention (I2).

The decision seems to be justified by the fact that, as I have already noted, there are only two options are provided legally for termination of pregnancy in Hungary, either in a hospital or in a clinic. However, women have the right to choose, thus they can opt for either local or general anesthesia, and, are also required to stay at the hospital for a few hours (or as it is advised) after the operation.
As far as contraception is concerned, modern methods of contraception are available in Hungary in clinics and pharmacies. In addition, family planning services are part of the National Health Service. Their main focus is on counselling, pre- and post-natal care. As an implied, but not expressed objective, family planning services intend to minimize the number of abortions. Fortunately, many claim that the quality of family planning services in the country is often low (I1).

\section{Abortion in the European Union}

Grégor Puppinck argues that ,in Europe, about $30 \%$ of pregnancies end in abortion. After more than thirty years of legal abortion in Europe, abortion should be addressed in an objective manner by looking to practice, experience, and ideological implications" (Puppinck, 2015, 29.). And he goes on to claim that "It is no longer possible to talk about abortion only in terms of progress and liberation for women. For medical practitioners and lawmakers, the realities of abortion in practice reveal a more complex issue" (Puppinck, 2015, 30.).

When there is a case may come up, the debate usually swings around two articles of the European Convention on Human Rights, namely, article 2 and article 8, (I2) and, both Articles can be found in Section I, RIGHTS AND FREEDOMS.

\section{ARTICLE 2: Right to life}

This article states that „everyone's right to life shall be protected by law. No one shall be deprived of his life intentionally save in the execution of a sentence of a court following his conviction of a crime for which this penalty is provided by law" (I2). Basically, one can go as far as to state that it is in accordance with the Fundamental law of Hungary, stating that "every human being shall have the right to life." (The Fundamental Law of Hungary - 
25 April 2011). Thus the state itself assumes and provides protection for any individuals.

\section{ARTICLE 8: Right to respect for private and family life}

This article affirms that "everyone has the right to respect for his private and family life, his home and his correspondence", moreover, it goes on to assert that "there shall be no interference by a public authority with the exercise of this right except such as is in accordance with the law and is necessary in a democratic society in the interests of national security, public safety or the economic wellbeing of the country, for the prevention of disorder or crime, for the protection of health or morals, or for the protection of the rights and freedoms of others"(I2).

It is also relevant to analyze the notion of those who advocate a right to abortion defend the idea that within the Convention system, "Member States are free to determine the availability and legal status of abortion"'(Zampas \& Gher, 2008 - in that article, the authors refer to part I, sections (b)(f) of Magda Krzyzanowski-Mierzewska, 2004, how to use the European Convention for the protection of human rights and fundamental freedoms in matters of reproductive law). While it is also true that States have the freedom to prohibit abortion, the European Court of Human Rights has said, regarding protections to the unborn child and mother, that Member States have a duty under the Convention to ban painful or forced abortions. Therefore, Member States are not totally free to determine the availability and legal status of abortion, but must balance the various legitimate interests and rights involved. But there are controversial circumstances and decisions, which appear to complicate the issue of termination of pregnancy further. Since Applicants in cases relating to abortion have invoked not just Article 2, but also Article 8, which protects "private and family life", Article 6, which guarantees, among other matters, "access to court" in the determination of a person's ,civil rights and obligations" and, as concerns the dissemination of information on abortion, Article 10, concerning freedom of expression (Korff, 2006).

In addition, it is important to note that there are several of the other arguments as well, since they are directly inter-related, and because the Convention organs have at times made comments in cases under those other articles which relate to Article 2. In consequence, in an early case, Bruggemann and Scheuten v. Germany, the applicant argued that she had the sole right to decide to have an abortion under Article 8 of the Convention, which guarantees the right to respect for "private life”. However, the Commission held that: Article 8 \& 1 cannot be interpreted as meaning that pregnancy and its termination are, as a principle, solely a matter of the private life of the mother while declining to examine the issue, in that case, under Article 2. However, in later cases it did take up the issue under that article. In the case of $X$ v. the United Kingdom, 15 the Commission noted that Article 2 of the Convention does not mention abortion (Korff, 2006).

In order to get a wider scope of the situation, it is crucial to examine some decisions as well, and, at least, to clarify some standpoints that might be regularly debated.

\section{A., B. and C. v. Ireland (application no. 25579/05)}

16 December 2010 (Grand Chamber)

The applicant were three women living in Ireland, who became pregnant involuntarily, complained that, because of the impossibility of obtaining a legal abortion in Ireland, they had to go to the United Kingdom for an abortion and that the procedure was humiliating, stigmatizing and risked damaging their health. Having or aiding anyone to have an abortion is a criminal offence in Ireland. However there is a constitutional right to an abortion where there is a real and substantial risk to the 
life of the mother. One of the applicants, in remission from a rare form of cancer and unaware that she was pregnant, underwent checkups contraindicated in pregnancy. She understood that her pregnancy could provoke a relapse and believed that it put her life at risk.

In her (applicant 1)case the Court found that Ireland had failed to implement the constitutional right to a legal abortion. There had therefore been a violation of Article 8 (right to respect for private and family life) of the Convention concerning the applicant in remission from cancer, but as for the other two applicants, the Court held there had been no violation of Article 8 (I2).

Applicant 1 was not able to institute her right to a legal abortion either through the courts or the medical services available in Ireland. The Court noted the uncertainty surrounding the process of establishing whether a woman's pregnancy posed a risk to her life and that the threat of criminal prosecution had a "significant chilling" effect both on doctors and the women concerned.

\section{Conclusion}

Grégor Puppinck, assumes that one may see changes concerning the debate around the termination of pregnancy, since he states that „the new cultural trend favorable to the protection of life faces opposition because it goes against the dominant culture inherited from the 1960s." (Puppinck, 2015,43.). As far as one can assume, it is in this context that the intention of some governments, like in France, to "standardize" abortion and to make it a fundamental right of women can be understood, but this „right, in order to exist and to survive, needs ,ignoring/neglecting” the rights of an embryo and human fetus as well. However, according to Grégor Puppinck, it can be stated that ,the progress of science and consciousness working together, slowly but indisputably, seems to have led to a better understanding of the development of a human being" (Puppinck, 2015, 43.). Bearing all in mind, the encouragement of abortion as an individual right appears in decline. Grégor Puppinck observes that this decline is due to two prevailing reasons: „through experience, one finds liberal legislation leads to unsatisfactory results, and through scientific reasoning, one finds that further progress prompts many more to reconsider the dignity of the human being from conception. The decline of the right to abortion is more challenging for society than its advance because it demands that we be more human, responsible, and united, in order to recognize and welcome the lives of persons at all stages of development" (Puppinck , 2015,43.).

Although one can imagine the statements made by Grégor Puppinck justified by sentimentalism, nostalgia, or faith, one should bear in mind the socalled progress he himself advocates gave way to equal rights movements, especially for women as well. I admit that socially, as far as social „standards" are concerned, a state should be very careful how to „advocate" or to „deal with” the termination of pregnancy, however, to be persecuted for not giving up one's own dignity and her free will to choose whether she wants to be a mother or not do not seem to be a progress at all. On the contrary, it offers a way back to the Middle Ages.

\section{References}

Bayles, M. D; Henley, K.(eds.) (1989) Right Conduct: Theories and Applications. Random, New York.

Korff, D. (2006). The Right to life: A guide to the implementation of Article 2 of the European Convention on Human Rights.(Strasburg: 2006), Human rights handbooks, No. 8, 9-11.

Krzyżanowska-Mierzewska, M. (2004). How to use the European Convention for the Protection of Human Rights and Fundamental Freedoms in matters of reproductive law: the case law of the European Court of Human Rights_GUIDE. 
Web. http://www.astra.org.pl/pdf/publications /astra_guide.htm

Puppinck, G. (2015). Abortion in European Law: Human Rights, Social Rights and the New Cultural Trend. Ave Maria International Law Journal, Vol. 4, No. 1. 29-43. web: http://9afb0ee4c2ca3737b892e804076442d956681ee1e5a58d07b27b.r59.cf2.r ackcdn.com/ECLJ\%20Docs/Abortion \%20In\% 20European $\% 20 \mathrm{Law} \% 20$ Ave $\% 20$ Maria\%20Intl $\% 20 \mathrm{~L} \% 20 \mathrm{~J} \% 202015 \% 20$ Puppinck.pdf

The Fundamental Law of Hungary -25 April 2011. 7-8.

Wolfgang P. Müller (2012). The Criminalization of Abortion in the West: Its Origins in Medieval Law. Cornell University Press, Ithaca.
Zampas, C. \& Gher, J. M. (2008). Abortion as a Human Right-International and Regional Standards. Hum. Rts. L. Rev. 249, 276.

Ziegler, M. (2018). Beyond Abortion: Roe v. Wade and the Battle for Privacy. Fellows of Harward College. United States of America.

I1:https://www.angloinfo.com/howto/hungary/healthcare/pregnancybirth/termination-abortion

I2: European Convention on Human Rights. European Court of Human Rights Council of Europe web: https://www.echr.coe.int /Documents/Convention ENG.pdf. 